\title{
Detection and prevention of protein aggregation before, during, and after purification
}

\author{
Sarah E. Bondos* and Alicia Bicknell ${ }^{1}$ \\ Department of Biochemistry and Cell Biology, Rice University, Houston, TX 77251-1892, USA
}

Received 4 November 2002

\begin{abstract}
The use of proteins for in vitro studies or as therapeutic agents is frequently hampered by protein aggregation during expression, purification, storage, or transfer into requisite assay buffers. A large number of potential protein stabilizers are available, but determining which are appropriate can take days or weeks. We developed a solubility assay to determine the best cosolvent for a given protein that requires very little protein and only a few hours to complete. This technique separates native protein from soluble and insoluble aggregates by filtration and detects both forms of protein by SDS-PAGE or Western blotting. Multiple buffers can be simultaneously screened to determine conditions that enhance protein solubility. The behavior of a single protein in mixtures and crude lysates can be analyzed with this technique, allowing testing prior to and throughout protein purification. Aggregated proteins can also be assayed for conditions that will stabilize native protein, which can then be used to improve subsequent purifications. This solubility assay was tested using both prokaryotic and eukaryotic proteins that range in size from 17 to $150 \mathrm{kDa}$ and include monomeric and multimeric proteins. From the results presented, this technique can be applied to a variety of proteins.
\end{abstract}

(C) 2003 Elsevier Science (USA). All rights reserved.

Keywords: Aggregation; Solubility; Inclusion bodies; Precipitation; Protein; Purification

Recombinant proteins are required in biological research to investigate enzyme activity, ligand binding, protein interactions, or other functions in vitro. Many proteins are also potential pharmaceutical agents [1-5]. One significant impediment to the study and utilization of proteins is their extreme sensitivity to solution conditions. Nonoptimal conditions during protein expression, purification, storage, or handling can alter protein structure such that the protein irreversibly aggregates, with concomitant loss of activity [4-7]. Proteins frequently aggregate at the high concentrations required for structural studies, and small soluble aggregates can be incorporated into protein crystals as defects [8-10]. Protein folding studies are often complicated by aggregation of intermediate and denatured states [9-13]. Further, point mutations or deletion mutations required

\footnotetext{
${ }^{*}$ Corresponding author. Fax: 1-713-348-6149.

E-mail address: bondos@bioc.rice.edu (S.E. Bondos).

${ }^{1}$ Present address: UCSD Biology Student Affairs 038, 9500 Gilman. Dr., La Jolla, CA 92093-0348, USA.
}

for relevant protein studies may destabilize the native state and expedite aggregation [14-16]. The kinetics of aggregation may be an order of magnitude faster than folding kinetics, causing a significant fraction of the protein to be inactivated [10]. Competition between aggregation and folding can have biological ramifications: protein aggregation in vivo is implicated in a variety of disorders, including Parkinson's disease, Alzheimer's disease, and spongiform encephalopathies [15-18]. In vitro examination of the proteins involved in these diseases will require strategies to control aggregation $[15,17]$. Thus, protein aggregation is a problem common to biological systems, experimental research, and industrial and medical applications.

To circumvent these problems, a wide variety of buffer cosolvents that can facilitate proper protein folding and solubility have been identified. Cosolvents exert their effects by either destabilizing aggregates or enhancing native protein stability [6,12,19-27]. Examples of useful additives are listed in Table 1. Aggregate formation can be deterred by including cosolvents that 
Table 1

Agents that may promote protein solubility

\begin{tabular}{|c|c|c|c|}
\hline & Additive & Recommended concentration range & Reference \\
\hline Kosmotropes & $\begin{array}{l}\mathrm{MgSO}_{4} \\
\left(\mathrm{NH}_{4}\right)_{2} \mathrm{SO}_{4} \\
\mathrm{Na}_{2} \mathrm{SO}_{4} \\
\mathrm{Cs}_{2} \mathrm{SO}_{4}\end{array}$ & $\begin{array}{l}0-0.4 \mathrm{M} \\
0-0.3 \mathrm{M} \\
0-0.2 \mathrm{M} \\
0-0.2 \mathrm{M}\end{array}$ & $\begin{array}{l}{[19]} \\
{[19]} \\
{[19]} \\
{[19]}\end{array}$ \\
\hline Weak kosmotropes & $\begin{array}{l}\mathrm{NaCl} \\
\mathrm{KCl}\end{array}$ & $\begin{array}{l}0-1 \mathrm{M} \\
0-1 \mathrm{M}\end{array}$ & $\begin{array}{l}{[7,19]} \\
{[19]}\end{array}$ \\
\hline Chaotropes & $\begin{array}{l}\mathrm{CaCl}_{2} \\
\mathrm{MgCl}_{2} \\
\mathrm{LiCl} \\
\mathrm{RbCl} \\
\mathrm{NaSCN} \\
\mathrm{NaI} \\
\mathrm{NaClO} \\
\mathrm{NaBr} \\
\text { Urea }\end{array}$ & $\begin{array}{l}0-0.2 \mathrm{M} \\
0-0.2 \mathrm{M} \\
0-0.8 \mathrm{M} \\
0-0.8 \mathrm{M} \\
0-0.2 \mathrm{M} \\
0-0.4 \mathrm{M} \\
0-0.4 \mathrm{M} \\
0-0.4 \mathrm{M} \\
0-1.5 \mathrm{M}\end{array}$ & $\begin{array}{l}{[19]} \\
{[19,30]} \\
{[19]} \\
{[19]} \\
{[19]} \\
{[19]} \\
{[19]} \\
{[19,30]} \\
{[6,12]}\end{array}$ \\
\hline Amino acids & $\begin{array}{l}\text { Glycine } \\
\text { L-arginine }\end{array}$ & $\begin{array}{l}0.5-2 \% \\
0-5 \mathrm{M}\end{array}$ & $\begin{array}{l}{[6]} \\
{[6]}\end{array}$ \\
\hline Sugars and polyhydric alcohols & $\begin{array}{l}\text { Sucrose } \\
\text { Glucose } \\
\text { Lactose } \\
\text { Ethylene glycol } \\
\text { Xylitol } \\
\text { Mannitol } \\
\text { Inositol } \\
\text { Sorbitol } \\
\text { Glycerol }\end{array}$ & $\begin{array}{l}0-1 \mathrm{M} \\
0-2 \mathrm{M} \\
0.1-0.5 \mathrm{M} \\
0-60 \% \mathrm{v} / \mathrm{v} \\
0-30 \% \mathrm{w} / \mathrm{v} \\
0-15 \% \mathrm{w} / \mathrm{v} \\
0-10 \% \mathrm{w} / \mathrm{v} \\
0-40 \% \mathrm{w} / \mathrm{v} \\
5-40 \% \mathrm{v} / \mathrm{v}\end{array}$ & $\begin{array}{l}{[4,11]} \\
{[21]} \\
{[21]} \\
{[38]} \\
{[38]} \\
{[38]} \\
{[38]} \\
{[29,30,38]} \\
{[39]}\end{array}$ \\
\hline Detergents & $\begin{array}{l}\text { Tween } 80 \\
\text { Tween } 20 \\
\text { Nonidet P-40 }\end{array}$ & $\begin{array}{l}0-0.2 \% \mathrm{w} / \mathrm{v} \\
0-120 \mu \mathrm{M} \\
0-1 \%\end{array}$ & $\begin{array}{l}{[4]} \\
{[5]} \\
{[42]}\end{array}$ \\
\hline
\end{tabular}

destabilize protein-protein interactions. For example, low concentrations of charged cosolvents can screen protein electrostatic interactions that may facilitate aggregation $[2,19,26]$. Another strategy utilizes chaotropic species to interact with the peptide group, replacing or preventing the intermolecular interactions that lead to aggregation $[6,12,25]$.

An alternate approach is to stabilize native intramolecular protein interactions, thus out-competing the intermolecular interactions that lead to aggregation. To this end, kosmotropes generally stabilize the native state of proteins [25-28]. Because kosmotropes increase the surface tension of the solvent, they are excluded from the protein-solvent surface. Therefore, the entropic cost of disturbing the distribution of small molecules to form the solvent cavity increases. Generally, the native state of globular proteins creates the smallest solvent cavity; therefore, kosmotropes raise the cost of hydrating intermediate or denatured states relative to the native state. Sugars and polyhydric alcohols, in particular, interact with the protein more weakly than water [26]. Optimization of the number of strong water-cosolvent interactions forces the cosolvent to be excluded from the protein surface, thus stabilizing the state with the smallest surface area $[21,26,27,29,30]$. The addition of such cosolvents not only stabilizes many proteins but also deters ice formation, thus inhibiting the deleterious effects of freezing on protein structure [4,5,26,27]. Finally, small amino acids are also preferentially excluded from the protein surface. However, charged amino acid salts may also interact with the protein at certain $\mathrm{pH}$ and salt concentrations $[2,26]$.

Other types of buffer additives may also facilitate protein solubility. Dithiothreitol and $\beta$-mercaptoethanol are reducing agents that prevent aggregation of some proteins by inhibiting the formation of nonnative disulfide bonds. Importantly, reduced glutathione is not as effective; the reduced form often contains a small percentage of oxidized glutathione which, ironically, may be sufficient to oxidize the protein [24]. Compounds such as trifluoroethanol or trichloroacetic acid prevent aggregation by stabilizing $\alpha$-helical structure [23]. Ethanol has been used to stabilize a folding intermediate by weakening hydrophobic interactions that facilitate aggregation [13]. Membrane proteins may require detergents or micelles to form their native structure [20,22]. 
The list of potential cosolvents that influence protein solubility may appear staggering to one who must determine a starting point. The following strategy may be useful to rapidly identify optimal solvent conditions for a given protein. First, cosolvents or additive concentrations that interfere with subsequent biochemical assays should be eliminated. Previous experience with the protein or a member of the protein family may suggest cosolvents that are likely to succeed. For example, many nucleic acid binding proteins often require higher salt concentrations, as demonstrated in this paper. For novel proteins, a good choice is to select one cosolvent from each category in Table 1, using a concentration in the middle of the suggested range. Chemicals and concentration ranges within a promising category can then be optimized in a subsequent assay.

When choosing a cosolvent, determination of the optimal concentration is critical. High concentrations of chaotropes will denature proteins, while high concentrations of kosmotropes will salt proteins out of solution. Consequently, removing ions from the buffer may enhance protein stability [17,31]. A list of many additives and appropriate concentration ranges can be found in Table 1 . Because any additive has the potential to alter protein conformation or activity, the effects of specific conditions on protein structure and function should be investigated by varying cosolvent concentration or comparing with a second stabilizing cosolvent [26]. A more extensive list of protein stabilizing reagents and descriptions of their mechanisms of action can be found in several excellent reviews [25-27].

The large number of potentially stabilizing cosolvents and the dependence of cosolvent effects on concentration complicates determination of optimal buffer conditions for a given protein. Often, such efforts rely on trial and error during protein purification. Alternately, sample turbidity can be measured to assay for protein aggregation. However, turbidity measurements require high concentrations of protein and cannot detect low concentrations of aggregates or small, soluble aggregates [3,32]. Further, turbidity requires purified samples, prohibiting its use for proteins that aggregate during expression or purification.

Here, we describe a facile method to identify buffers that maintain soluble, native protein. This technique can distinguish precipitates and small, soluble aggregates from native protein. Multiple buffers or proteins can be screened in just a few hours. Importantly, this solubility assay can be applied to protein mixtures and crude lysates, allowing assessment of protein stability throughout a protein purification protocol. This solubility assay was demonstrated for a variety of applications, including screening buffers to inhibit aggregation in functional assays, screening mutant proteins for aggregation, screening for solubility of a single protein in heterogeneous mixtures, assaying aggregated proteins for stabilizing conditions, and screening inclusion bodies in crude cell lysates for stabilizing conditions. Both prokaryotic and eukaryotic proteins were tested, including monomeric and multimeric proteins ranging in size from 17 to $150 \mathrm{kDa}$. Therefore, this solubility assay can be utilized for a wide variety of proteins.

\section{Materials and methods}

\section{Protein expression and purification}

The proteins used to test the aggregation assay are Bacillus anthracis ATXA, Eschericia coli LacI, Drosophila melanogaster UDK-c, Drosophila melanogaster Ultrabithorax (Ubx), and Brachydanio rerio LMO4. ATXA protein was a gift of Dr. Edward Nikonowicz from Rice University. The LacI mutants L148F, S151P, G60+3-11, and Q60P-11 were provided by Hongli Zhan and Dr. Kathleen Matthews from Rice University. UDC-c was given by Daniel J. Catanese and Dr. Kathleen Matthews from Rice University. LMO4 crude lysates, purified protein, and GN5049 primary antibody were gifts of David Ji and Dr. Mary Ellen Lane from Rice University.

Ubx contaminated with proteolysis products and fulllength Ubx were purified for use in the solubility assay. The Ubx expression construct pET-Ubx-3c, a gift from Dr. Phillip A. Beachy (The Johns Hopkins University School of Medicine), was transformed into the E. coli strain BL21(DE3)pLysS. Twelve flasks containing 1 liter of Luria broth plus $50 \mu \mathrm{g} / \mathrm{ml}$ carbenicillin cultures were each inoculated with $10 \mathrm{ml}$ of overnight culture and grown at $37^{\circ} \mathrm{C}$ to mid-log. The cultures were cooled to room temperature prior to Ubx induction with $1 \mathrm{mM}$ isopropyl $\beta$-L-thiogalactoside. Cells were harvested $2 \mathrm{~h}$ after induction and frozen.

To purify Ubx, a cell pellet was lysed in $20 \mathrm{ml}$ of $50 \mathrm{mM}$ Tris- $\mathrm{HCl}, 4 \mathrm{mM}$ DTT, ${ }^{2} 800 \mathrm{mM} \mathrm{NaCl}, 20 \mu \mathrm{g} / \mathrm{ml}$ DNase, and $1 \mathrm{mM}$ phenylmethyl sulfonyl fluoride. Lysis supernatant was treated with polyethyleneimine and centrifuged. The $\mathrm{pH}$ of the supernatant was adjusted to 6.8 and centrifuged to remove precipitates. The final supernatant was loaded onto a phosphocellulose column, washed with Buffer Z (10\% glycerol, $0.5 \mathrm{mM}$ DTT, $0.1 \mathrm{mM}$ EDTA, $25 \mathrm{mM} \mathrm{NaH} \mathrm{PO}_{4}, 100 \mathrm{mM} \mathrm{NaCl}, \mathrm{pH}$ 6.8 ), and eluted with a 0 to $1 \mathrm{M} \mathrm{NaCl}$ gradient in Buffer $\mathrm{Z}$. Ubx mixed with $\mathrm{N}$-terminal proteolytic products was assayed for aggregation at this point in the purification. Fractions containing Ubx were dialyzed against 4 liters of $50 \mathrm{mM}$ Tris- $\mathrm{HCl}, 100 \mathrm{mM} \mathrm{NaCl}, 1 \mathrm{mM}$ DTT, $10 \%$

\footnotetext{
${ }^{2}$ Abbreviations used: DTT, dithiothrectol; EMSA, electrophoretic mobility shift analysis.
} 
Table 2

Proteins used in the aggregation assay and relevant parameters

\begin{tabular}{|c|c|c|c|c|c|}
\hline Protein & Source & Filter used & $\begin{array}{l}\text { Initial } \\
\text { concentration }\end{array}$ & $\begin{array}{l}\text { SDS-PAGE } \\
\text { detection }\end{array}$ & $\begin{array}{l}\text { Molecular weight } \\
\text { and assembly }\end{array}$ \\
\hline ATXA & Bacillus anthracis & 100 kDa MW cut-off Microcon & $0.16 \mathrm{mM}$ & Silver stain & $50 \mathrm{kDa}$, monomer \\
\hline LacI: & Escherichia coli & Ultrafree-MC filter unit & & Silver stain & \\
\hline L148F & & & $0.67 \mathrm{mM}$ & & $150 \mathrm{kDa}$, tetramer \\
\hline S151P & & & $0.60 \mathrm{mM}$ & & $150 \mathrm{kDa}$, tetramer \\
\hline $\mathrm{G} 60+3-11$ & & & $1.10 \mathrm{mM}$ & & $65 \mathrm{kDa}$, dimer \\
\hline Q60+3-11 & & & $0.84 \mathrm{mM}$ & & $65 \mathrm{kDa}$, dimer \\
\hline UDKc-his & Drosophila melanogaster & 100 kDa MW cut-off Microcon & $3.6 \mu \mathrm{M}$ & Western blotting & $47 \mathrm{kDa}$, monomer \\
\hline $\mathrm{UbxIb}$ & Drosophila melanogaster & 100 kDa MW cut-off Microcon & $13 \mu \mathrm{M}$ & Western blotting & $40 \mathrm{kDa}$, monomer \\
\hline LMO4 & Brachydanio rerio & 100 kDa MW cut-off Microcon & $5 \mu \mathrm{M}$ & Western blotting & $17 \mathrm{kDa}$, monomer \\
\hline
\end{tabular}

glycerol, pH 8.0 for $1 \mathrm{~h}$. Ni-NTA resin (Qiagen) was equilibrated in dialysis buffer, added to the dialysate, and mixed on a Nutator at $4{ }^{\circ} \mathrm{C}$ for $1 \mathrm{~h}$. The resulting slurry was washed with $10 \mathrm{ml}$ of buffer containing $50 \mathrm{mM} \mathrm{NaH}_{2} \mathrm{PO}_{4}, 300 \mathrm{mM} \mathrm{NaCl}, 5 \%$ glucose at $\mathrm{pH} 8.0$. plus $10 \mathrm{mM}$ imidazole followed by $25 \mathrm{ml}$ of the same buffer with $20 \mathrm{mM}$ imidazole. Ubx was eluted in $10 \mathrm{ml}$ of the buffer containing $100 \mathrm{mM}$ imidazole. Protein was stored at $4{ }^{\circ} \mathrm{C}$ after the addition of DTT to $5 \mathrm{mM}$ and assayed the following day.

\section{Aggregation assay}

The general strategy was to simultaneously test up to 14 solution conditions on small samples of purified or unpurified protein. Soluble protein was then separated from aggregates and precipitates by filtration. The molecular weight cut-off of the filter was chosen such that soluble protein was allowed to pass through the filter, while aggregate forms were retained.

In more detail, protein was diluted or dialyzed into a series of buffer conditions such that the final volume was $100-120 \mu 1$. Initial protein concentrations ranged from 3 to $1 \mathrm{mM}$ (see Table 2). The diluted protein was incubated at room temperature in the test buffer for $1 \mathrm{~h}$. Soluble protein was then separated from aggregated protein using a Microcon concentrator (Millipore), with a molecular weight cut-off of $100 \mathrm{kDa}$. The UltrafreeMC 0.1- $\mu \mathrm{m}$ filter unit (Millipore) was used for experiments on LacI mutants to accommodate the larger proteins. The Microcon or filter unit was spun in a desktop centrifuge at $16,000 \mathrm{~g}$ for $15 \mathrm{~min}$. Aggregated protein retained on the membrane was resuspended in $30 \mu \mathrm{l}$ of $\mathrm{dH}_{2} \mathrm{O}$, pipeting repeatedly across the membrane to ensure that as much protein as possible is removed. Samples of $30 \mu$ soluble protein and $30 \mu 1$ aggregated protein were each mixed with $10 \mu \mathrm{l}$ of $4 \times$ sample buffer (250 mM Tris- $\mathrm{HCl}, 40 \%$ glycerol, $140 \mathrm{mM}$ SDS, $0.6 \mathrm{M}$ $\beta$-mercaptoethanol, $\mathrm{pH} 6.8$ ) and heated to $85-90^{\circ} \mathrm{C}$ for $10 \mathrm{~min}$ prior to SDS-PAGE. Because soluble protein and aggregated protein were assayed separately, small changes in either population can be readily observed.
Detection of aggregates is especially sensitive because nearly half of the recovered aggregated protein retained by the filter is loaded on the gel. The final protein concentration required is dependent on the detection method used. Coomasie staining detects $0.05-0.5 \mu \mathrm{g}$ of protein per band, silver staining detects $1-5 \mathrm{ng}$ of protein per band, and Western blotting detects less than $1 \mathrm{pg}$ of protein per band ([23], www5.amershambiosciences.com).

\section{Results}

The solubility assay was developed for use in situations spanning the lifetime of a protein from cell lysis, purification, and exchange into assay buffers. For simplicity, the straightforward application of assaying soluble protein for conditions that diminish aggregation is presented first. The subsequent experiments, including analyzing solubilization of aggregated protein and analyzing protein mixtures, increase in complexity. The section concludes with assaying inclusion bodies in crude cell lysates for conditions that will allow protein solubilization. This last application is the most useful, allowing optimization of cosolvents prior to purification.

Example of screening buffers to enhance solubility of purified protein during functional assays

Buffer conditions required for column binding and protein elution are often incompatible with functional and structural analysis. Initial purifications of the $B$. anthracis protein ATXA resulted in precipitation of some product. Further, gel retardation assays of DNA binding by the soluble protein fraction exhibited density in the wells, indicative of ATXA aggregation. Buffer conditions were screened for stabilization of native ATXA and prevention of aggregation in DNA binding assays (Fig. 1). Buffer additives were limited to salt and glycerol, which are normal components of buffers in DNA binding assays, and cosolvent concentrations 


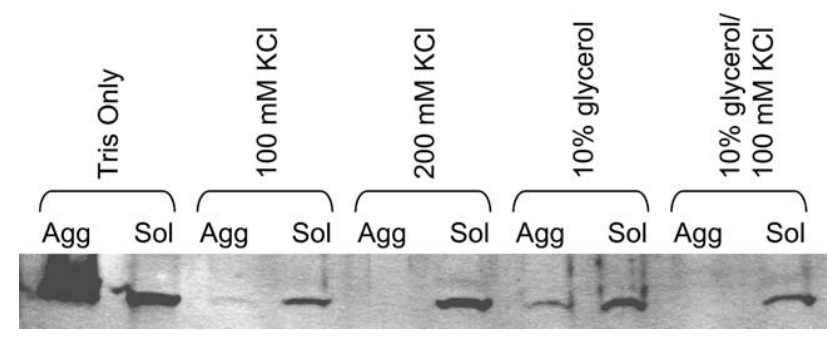

Fig. 1. Solubility assay of ATXA protein to identify an appropriate DNA binding buffer. To dilute the protein into assay buffers, $10 \mu \mathrm{l}$ of $0.16 \mathrm{mM}$ protein was added to $100 \mu \mathrm{l}$ of the five test buffers. All buffers contain $20 \mathrm{mM}$ Tris- $\mathrm{HCl}, \mathrm{pH}$ 7.5. ATXA was detected by silver staining. The soluble, native protein fraction is indicated by Sol, and the aggregated protein fraction is indicated by Agg. While ATXA aggregates in buffer containing $10 \%$ glycerol or $100 \mathrm{mM} \mathrm{KCl}$, no aggregation was observed in buffer containing both $10 \%$ glycerol and 100 or $200 \mathrm{mM} \mathrm{KCl}$. The variation in total protein observed for each buffer condition is repeatable and thus most likely reflects adhesion to the filter used in the assay.

were optimized within an acceptable range for DNA binding assays. Severe aggregation was detected in buffer containing only $20 \mathrm{mM}$ Tris, $\mathrm{pH}$ 8.0. Aggregation was also visible when $100 \mathrm{mM} \mathrm{KCl}$ or $10 \%$ glycerol was added. However, inclusion of $200 \mathrm{mM} \mathrm{KCl}$ prevented aggregation. Thus, the protein is sensitive to low salt conditions. Interestingly, while neither $100 \mathrm{mM} \mathrm{KCl} \mathrm{nor}$ $10 \%$ glycerol alone can prevent aggregation, a combination of both additives maintains soluble protein. The efficacy of combinations of cosolvents has been observed in other proteins also [6]. This assay provided two useful solution conditions for performing functional assays, which is important because DNA binding is profoundly affected by alterations in salt and glycerol concentrations [33-35]. Therefore, the solubility assay can successfully identify buffers that stabilize soluble protein.

\section{Example of screening mutant proteins for aggregation}

Mutations can dramatically alter the structure, stability, or aggregation properties of a protein. Even though mutant proteins may purify like wild-type protein, mutations may alter protein solubility. Proteins with mutations in the full-length tetrameric lactose repressor, $L a c \mathrm{I}$, and the dimeric deletion mutant, -11 LacI [36,37], were assayed for aggregated contaminants after storage at $-80^{\circ} \mathrm{C}$ (Fig. 2). Ultrafree-MC $0.1-\mu \mathrm{m}$ filter units were used to ensure sufficiently large pore size to accommodate the $65-\mathrm{kDa}$ dimers and the $150 \mathrm{kDa}$ monomers. The $0.1-\mu \mathrm{m}$ pore size is approximately 15 times the size of the $-11 \mathrm{LacI}$ dimer. Each mutant protein was diluted 1:100 into $20 \mathrm{mM}$ Tris, $\mathrm{pH} \mathrm{7.5,}$ $100 \mathrm{mM} \mathrm{KCl}$, and $10 \%$ glycerol. As a positive control, the L148F LacI mutant was also diluted into water, thus forcing aggregation and precipitation. The high protein
A

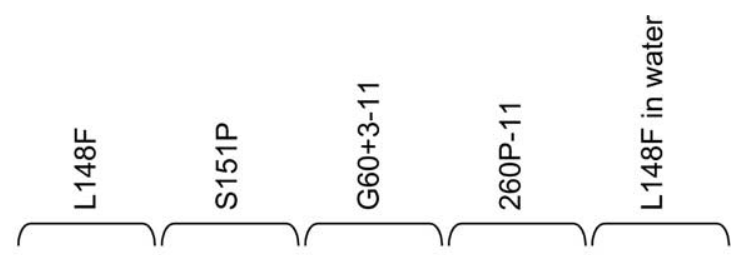

Agg W SolAgg W SolAgg W SolAgg W SolAgg W Sol
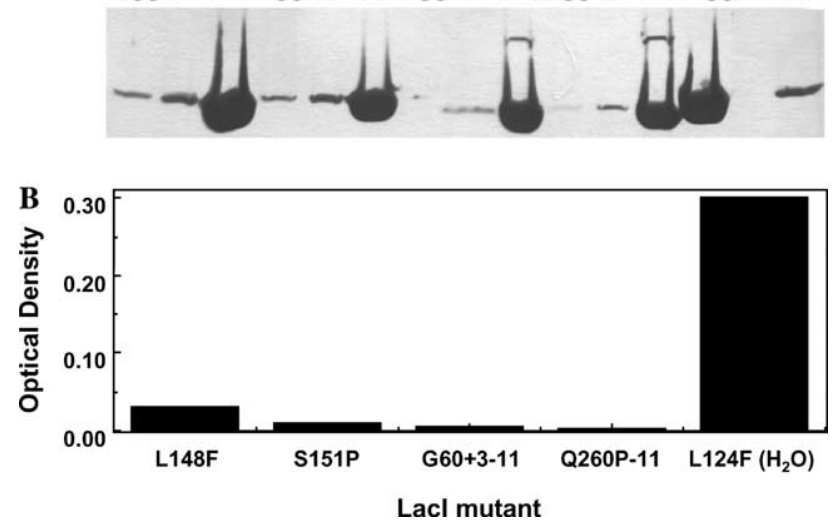

Fig. 2. (A) Solubility assay of $L a c$ I tetrameric and dimeric mutants. Each mutant was diluted 1:100 into buffer containing $20 \mathrm{mM}$ Tris$\mathrm{HCl}, \mathrm{pH} 7.5,100 \mathrm{mM} \mathrm{KCl}$, and $10 \%$ glycerol. Initial protein concentrations ranged from 0.6 to $1.1 \mathrm{mM}$. The positive control contains the L148F mutant diluted into Millipore water. LacI proteins were visualized by silver staining. The soluble protein is indicated by Sol, the filter unit wash by W, and the aggregated protein by Agg. (B) Turbidity of each sample, as measured by the optical density at $600 \mathrm{~nm}$. The turbidity results correlate with the density in the corresponding Agg lane.

concentrations used in this assay raised concerns that residual native protein left on the wet filter might be erroneously interpreted as aggregate. To prevent this problem, the membranes were washed by filtering with an additional $100 \mu l$ of buffer or water after separation of native and aggregated protein. Any native protein left on the filter after the wash should be below the detection limits of silver staining.

As expected, the majority of the protein in the water control was retained by the filter, indicating that the filter was capable of separating native and aggregated protein. While the different LacI and -11 LacI mutants were primarily native, aggregation was detected in the tetrameric L148F and S151P samples. Both -11 mutants had little or no aggregates. Most of the positive control, $L a c I$ in water, was retained by the filter, demonstrating that a $0.1-\mu \mathrm{m}$ filter can retain large amounts of aggregated $L a c$ I. Concerns that small concentrations of $L a c I$ aggregates might not be retained on filters with the very large pore size prompted comparison of the turbidity at $600 \mathrm{~nm}$ prior to sample filtration (Fig. 2B). The turbidity measurements correlate very well with the density of the band in the retentates, verifying that dimeric mutants can be assayed using the $0.1-\mu \mathrm{m}$ filter. Thus, the solubility assay works well using filters with larger pore sizes and can be applied to multimeric proteins. 


\section{Screening for aggregation of a partially purified protein}

Because solubility is monitored by SDS-PAGE, aggregation of a single component can be detected in a mixture of proteins. An interesting example is provided by the $D$. melanogaster protein Ultrabithorax $\mathrm{Ib}(\mathrm{Ubx})$. Ubx is not produced as inclusion bodies and does not precipitate during purification. However, a portion of the protein originally remained in the wells during electrophoretic mobility shift analysis (EMSA) to measure DNA binding, an indication of protein aggregation. A partially purified sample with contaminating $\mathrm{N}$-terminally degraded Ubx was used to assay buffers that potentially stabilize full-length, Ubx (Fig. 3A). Fulllength Ubx aggregates were detected in buffers containing low concentrations of salt. However, none of the degradation products precipitated under low-salt conditions; therefore, either the salt-sensitive region of $\mathrm{Ubx}$ must reside in the $\mathrm{N}$-terminal region or the structure must be altered upon removal of this region. Buffers for the remainder of the purification were adjusted to include $100 \mathrm{mM} \mathrm{NaCl}$ and $5-10 \%$ glycerol or glucose. Full-length purified Ubx was also assayed (Fig. 3B). The results for purified, full-length Ubx match the protein mixture. These results indicate that interactions with proteolysis products do not influence the aggregation behavior of full-length Ubx and confirm that the $\mathrm{N}$ terminus of Ubx contains a domain sensitive to salt concentration. The use of Ubx purified under the new

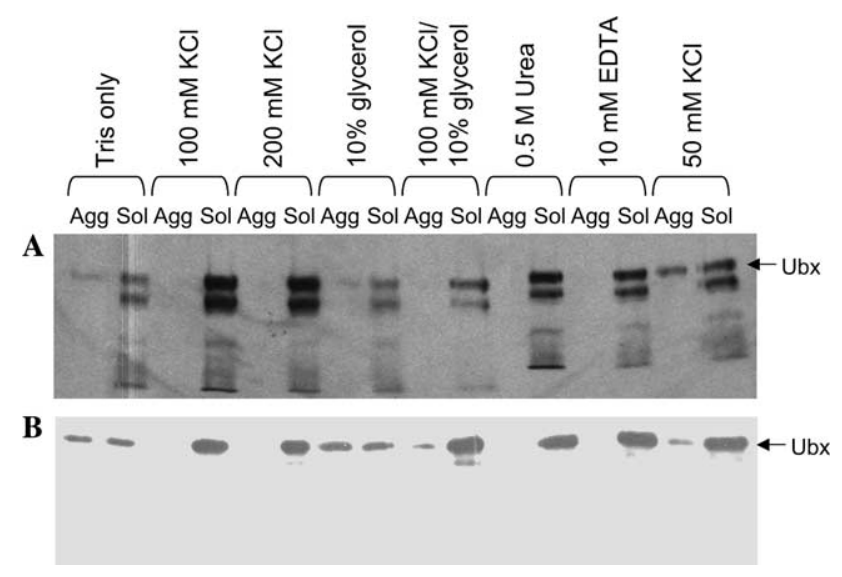

Fig. 3. Solubility assay using a protein mixture. Ubx protein bands on a $10 \%$ SDS-PAGE gel were detected by Western blotting, using FP3.38 as the primary antibody [41]. Ubx, $10 \mu \mathrm{l}$, was diluted with $100 \mu \mathrm{l}$ of test buffers. All buffers contain $20 \mathrm{mM}$ Tris, $\mathrm{pH}$ 8.0. (A) Aggregation assay of a mixture containing full-length Ubx and its $\mathrm{N}$ terminal degradation products. The top band is full-length Ubx, and the bottom bands are $\mathrm{N}$-terminal proteolysis products. Ubx aggregates in buffer with no additives, buffer with $50 \mathrm{mM} \mathrm{KCl}$, and buffer with $10 \%$ glycerol. However, Ubx did not aggregate in buffers with higher salt concentrations or with EDTA. (B) Aggregation assay of purified full-length Ubx. The behavior of purified Ubx matches the behavior of the mixture of full-length in a mixture with proteolyzed Ubx. Lanes are labeled as in Fig. 1. buffer conditions for EMSA experiments abrogated the signal caused by protein trapped in the wells, thus confirming the solubility assay results (data not shown). Thus, aggregation of a single protein in a protein mixture can be reliably assessed using the solubility assay.

\section{Example of assaying aggregated protein for stabilizing conditions}

Many proteins precipitate upon purification to homogeneity. Therefore, it is desireable to be able to use aggregated protein to assay buffers that will stabilize the native, soluble form. The $D$. melanogaster protein UDKc, also named UbxBP1, DIP1-c, and KLETT-c, originally precipitated after purification on a Ni-NTA column (Qiagen) via a histidine tag. The microfiltration solubility assay was used on purified, precipitated protein to determine buffer conditions that would maintain native UDKc during subsequent purifications (Fig. 4A). Precipitation may be irreversible; therefore, the presence of any soluble protein indicates a condition that may prevent protein aggregation. UDKc-his, a histidine-
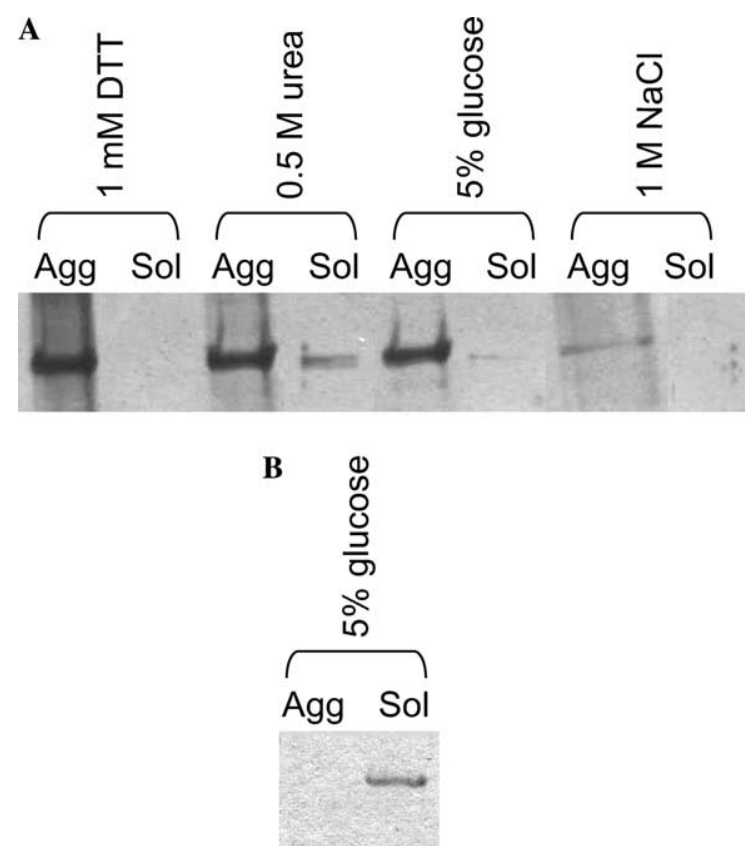

Fig. 4. Solubility assay of aggregated UDKc-his, a his-tagged RNA binding protein. Aggregated UDK-c was purified using Ni-NTA resin (Qiagen) and following the protocols therein. Protein bands on a $10 \%$ SDS-PAGE gel were detected by western blot using mouse anti tetrahis (Qiagen) as the primary antibody. (A) UDKc-his at $3.6 \mu \mathrm{M}$ was dialyzed into four test buffers. Each buffer contains $50 \mathrm{mM}$ sodium phosphate, $150 \mathrm{mM} \mathrm{NaCl}, 10 \mathrm{mM}$ imidazole, $\mathrm{pH} 8.0$, in addition to the cosolvents indicated. Lanes are labeled as in Fig. 1. Addition of both urea and $5 \%$ glucose increased the amount of soluble UDKc-his. (B) Aggregation assay of $100 \mu \mathrm{l}$ of $5.1 \mu \mathrm{M}$ UDKc-his similarly purified with all buffers containing $5 \%$ glucose. All of the protein is in the flowthrough, demonstrating that inclusion of glucose in the purification buffers prevents aggregation of UDKc-his. 
tagged construct that produces a $47-\mathrm{kDa}$ protein, was dialyzed into different buffers to maintain the protein concentration at detectable levels. Buffer containing urea, and to a lesser extent 5\% glucose, decreased aggregation of the protein. Because urea might affect subsequent biophysical characterization, 5\% glucose was selected as a purification additive for subsequent purifcations. A second solubility assay using UDKc-his protein purified in buffers containing $5 \%$ glucose revealed that the protein did not aggregate under the new buffer conditions (Fig. 4B). In a single afternoon, application of the solubility assay to precipitated protein successfully predicted conditions that would stabilize the native state of the protein, allowing protein purification and long-term storage.

\section{Screening for solubilization of inclusion bodies}

Many proteins, including the $B$. rerio (zebrafish) zinc finger protein LMO4, are expressed as inclusion bodies in E. coli. Purification then has the added onus of restoring the protein to its native, soluble state. Crude lysate containing $8 \mathrm{M}$ urea was assayed for conditions that enhance LMO4 solubility during purification (Fig. $5 \mathrm{~A})$. Due to the large number and high concentration of other proteins in the mixture, Western blotting was used to visualize LMO4 after SDS-PAGE. Because the protein is produced as inclusion bodies, determination of buffer conditions that will maintain soluble, native LMO4 was expected to be difficult. Therefore 12 co- solvents that address a broad range of potential triggers for aggregation, such as exposure of hydrophobic groups, charge-charge interactions, and cysteine oxidation, were selected for examination using the solubility assay. All test buffers contained $50 \mathrm{mM}$ Tris- $\mathrm{HCl}, \mathrm{pH}$ 8.0, $1 \mathrm{mM} \mathrm{ZnSO}_{4}$, and at least $100 \mathrm{mM} \mathrm{KCl}$. The density of both aggregated and soluble LMO4 for several buffer conditions is very light. This light density is repeatable and therefore not an artifact of gel loading or aggregate resuspension. The most likely explanation is that LMO4 adopts a conformation capable of irreversibly adhering to the membrane or the plastic casing in the filtration device under these buffer conditions. The only buffer to yield a substantial percentage of LMO4 in the soluble fraction contained $10 \mathrm{mM}$ DTT, indicating that protein oxidation likely triggered LMO4 aggregation.

To determine whether the proteins, lipids, and DNA in the crude lysate had influenced LMO4 solubility, precipitated LMO4 purified without DTT was assayed in the same buffers (Fig. 5B). While some LMO4 was observed in the flow-through of buffers containing urea, arginine, and trichloroacetic acid, all of the protein diluted into buffer containing $10 \mathrm{mM}$ DTT was in the filtrate. Therefore, use of the solubility assay to analyze the solution behavior of proteins in mixtures and crude lysate can predict the behavior of purified proteins. Assaying crude lysates is an effective strategy for designing purification protocols for novel proteins or proteins with a history of aggregation or precipitation. Upon growth of a purification-scale batch of E. coli, a

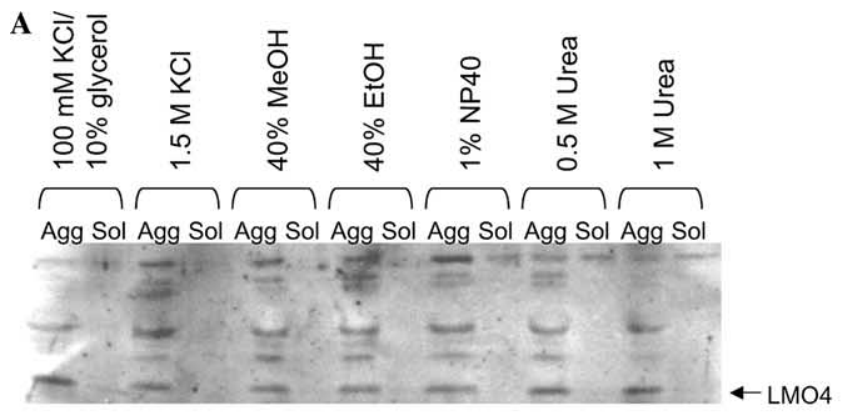

B
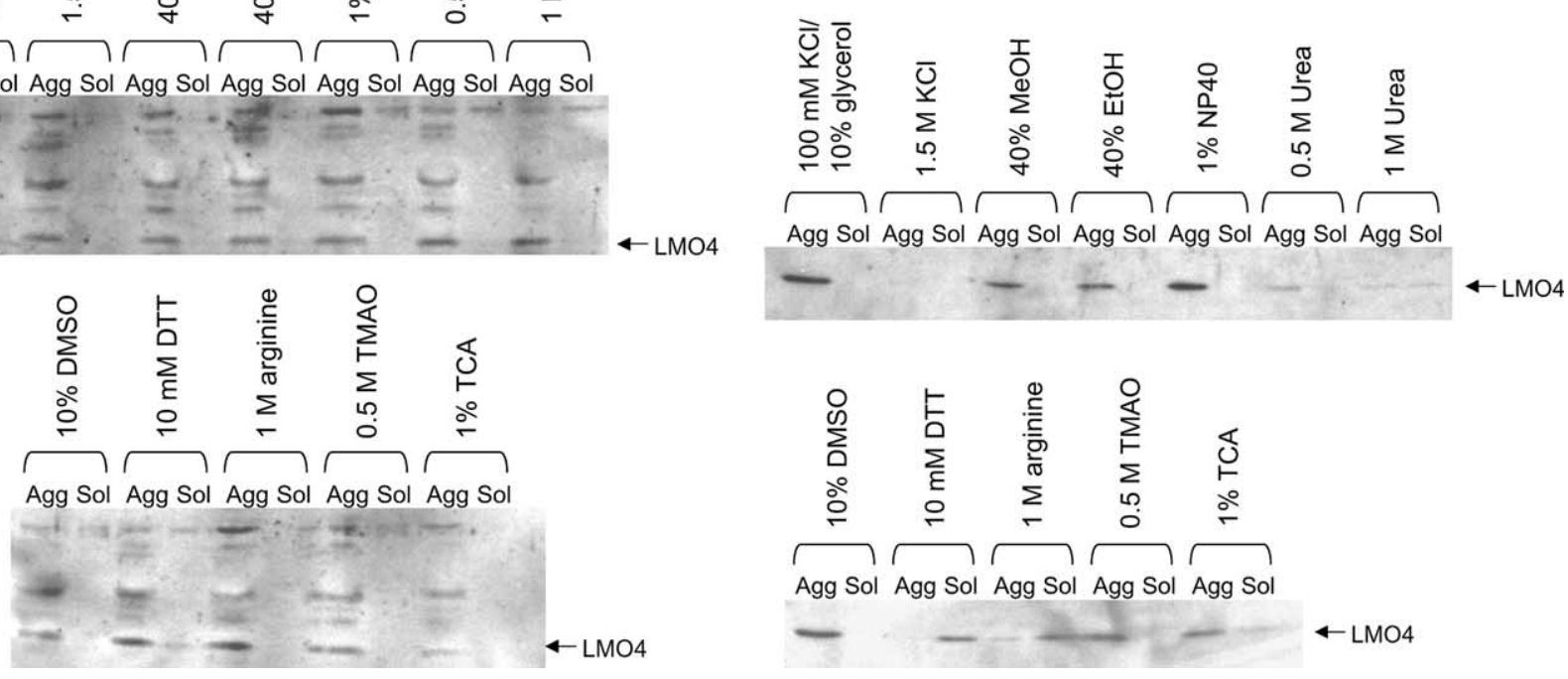

Fig. 5. Solubility assay using crude lysate. Ten microliters of both the crude lysate and the purified protein were diluted into $100 \mu$ l of test buffer. All buffers contain $50 \mathrm{mM}$ Tris- $\mathrm{HCl}, \mathrm{pH} 8.0,1 \mathrm{mM} \mathrm{ZnSO}_{4}$, and at least $100 \mathrm{mM} \mathrm{KCl}$. LMO4 protein was detected by Western blot using the rabbit antiLMO4 antibody GN5049. (A) Analysis of LMO4 in crude lysate containing $8 \mathrm{M}$ urea. Only the buffer containing $10 \mathrm{mM}$ DTT contains a substantial percentage of LMO4 in the flow-through. (B) Analysis of LMO4 purified in buffer containing $8 \mathrm{M}$ urea. All of the LMO4 protein is in the flowthrough for the $10 \mathrm{mM}$ DTT sample. Lanes are labeled as in Fig. 1. 
small aliquot of protein-expressing cells should be frozen separately. This aliquot can be lysed and the protein solubility tested, allowing adjustment of the purification buffers to suit the needs of the protein prior to the initial protein purification. This strategy saves a substantial amount of time and supplies compared to an iterative trial and error approach to protein purification.

\section{Discussion}

Effective screening of many possible additives at various concentrations requires a rapid assay for protein solubility. However, efforts to identify optimal buffer conditions often rely on repurification or functional assays, a time- and protein-consuming trial and error approach. Alternately, the turbidity, or light scattered by precipitates at a nonabsorbing wavelength, can be used to rapidly detect insoluble protein aggregates. Turbidity measurements require large volumes of at least $10 \mu \mathrm{M}$ final protein concentration [3]. The yields of many protein preparations are too low to allow screening by buffer dilution. Because turbidity is dependent on the molecular weight and the radius of gyration, the size or shape of the aggregates influence the outcome [32]. In addition, impure protein cannot be assayed. Finally, small soluble aggregates or low percentages of aggregates can impact protein function or create point defects in crystal growth, but are not detectable with turbidity measurements [10].

Here, we describe a sensitive method to simultaneously screen a large number of conditions for soluble or insoluble aggregates in a few hours. Because the assay separates the species by size, small soluble aggregates can be separated from native protein and detected. Aggregation of a single protein in a mixture can be detected, allowing analysis of partially purified protein or unpurified lysates. The analysis of both partially purified Ubx- and LMO4-containing crude lysate matched the results from the corresponding purified protein. Thus, this solubility assay can be used to screen for aggregated protein before, during, or after protein purification. A useful approach to a novel or difficult protein purification would be to use a small aliquot of $E$. coli expressing the protein of interest for analysis using the solubility assay. The required cosolvents could then be included in the protein purification buffers, dramatically increasing the probability of success. Previously aggregated protein can also be assayed to search for conditions that will prevent aggregation during subsequent purifications.

Some proteins may adhere to the filter units used in the assay under certain buffer conditions. Even this situation would be detectable. The protein would repeatedly not be present in the flow-through or the retentate under one or more buffer conditions, reflecting irreversible loss in the filter (for example, see Fig. 5B
(LMO4 in $1.5 \mathrm{M} \mathrm{KCl}$ )). Because the Durapore membrane in the Ultrafree MC filter unit binds only $4 \mu \mathrm{g} / \mathrm{cm}^{2}$ protein, this filter may be better for "sticky" proteins than the regenerated cellulose filters used in the Microcon [40]. Proteins may also adhere to the plastic tubes used in the assay. In this case, tubes treated with chlorinated organopolysiloxane in heptane to reduce protein adhesion may be used.

The aggregation assay was successfully tested on five proteins from both prokaryotic and eukaryotic organisms. Monomeric and multimeric proteins, ranging in size from 17 to $135 \mathrm{kDa}$, were examined in these experiments. From these results, we expect this assay to be generally applicable for rapid analysis of a wide range of proteins. The total time needed to optimize purification and buffers for functional assays for all five proteins was less than 2 weeks, a tremendous savings in time and material. This assay can be applied to proteins at all stages of purification, eliminating the necessity for trial and error approaches to optimize purification buffers.

\section{Acknowledgments}

This work was supported by grants to Dr. Kathleen S. Matthews from the NIH (GM22441) and the Robert A. Welch Foundation (C-576). We are grateful to Dr. Philip Beachy (Johns Hopkins University), Dr. Edward Nikonowicz (Rice University), and Dr. Mary Ellen Lane (Rice University) for supplying proteins and antibodies. We are grateful to the members of the Matthews laboratory for $L a c I$ and UDKc-his protein samples and helpful discussions. We especially thank Dr. Liskin Swint-Kruse for encouraging us to write this paper and Dr. Kathleen S. Matthews for critical discussions and comments on the manuscript.

\section{References}

[1] M. García, M. Monge, G. León, S. Lizano, E. Segura, G. Solano, G. Rojas, J.M. Gutiérrez, Effect of preservatives on IgG aggregation, complement-activating effect and hyposensitive activity of horse polyvalent antivenom used in snakebite envenomation, Biologicals 30 (2002) 143-151.

[2] L. Sharme, J. Baker, A.M. Brooks, A. Sharma, Study of IgM aggregation in serum of patients with macroglobuilinemia, Clin. Chem. Med. 38 (2000) 759-764.

[3] J.M. Sarciaux, S. Mansour, M.J. Hageman, S.L. Nail, Effects of buffer composition and processing conditions on aggregation of bovine IgG during freeze-drying, J. Pharm. Sci. 88 (1999) 1354 1361.

[4] B.A. Kerwin, M.C. Heller, S.H. Levin, T.W. Randolph, Effects of Tween 80 and sucrose on acute short-term stability and long-term storage at $-20^{\circ} \mathrm{C}$ of a recombinant hemoglobin, J. Pharm. Sci. 87 (1998) 1062-1068.

[5] L. Kreilgaard, L.S. Jones, T.W. Randolph, S. Frokjaer, J.M. Flink, M.C. Manning, J.F. Carpenter, Effect of Tween 20 on 
freeze-thawing and agitation-induced aggregation of recombinant human factor XIII, J. Pharm. Sci. 87 (1998) 1597-1603.

[6] H. Lu, H. Zhang, Q. Wang, H. Yuan, W. He, Z. Zhao, Y. Li, Purification, refolding of hybrid hIFN $\gamma$-Kringle 5 expressed in Eschericia coli, Curr. Microbiol. 42 (2001) 211-216.

[7] J.E. Wilson, L.L. Wright, J.L. Martin, S.E. Haire, P.H. Ray, G.R. Painter, P.A. Furman, Recombinant human immunodeficiency virus type I reverse transcriptase is heterogeneous, J. Acq. Immun. Def. Synd. 11 (1996) 20-30.

[8] D.N. Petsev, B.R. Thomas, S.-T. Yau, P.G. Vekilov, Interactions and aggregation of apoferritin molecules in solution: effects of added electrolystes, Biophys. J. 78 (2000) 2060-2069.

[9] S.E. Bondos, S. Sligar, J. Jonas, High pressure denaturation of apomyoglobin, Biochim. Biophys. Acta 1480 (2000) 353-364.

[10] M.E. Goldberg, R. Rudolph, R. Jaenicke, A kinetic study of the competition between renaturation and aggregation during the refolding of denatured-reduced egg white lysozyme, Biochemistry 30 (1991) 2790-2797.

[11] J.N. Webb, S.D. Webb, J.L. Cleland, J.F. Carpenter, T.W. Randolph, Partial molar volume, surface area, and hydration changes for equilibrium unfolding and formation of aggregation transition state: high pressure and cosolute studies on recombinant human IFN- $\gamma$, Proc. Natl. Acad. Sci. USA 98 (2001) 72597264.

[12] F. Edwin, Y.V. Sharma, M.V. Jagannadham, Stabilization of molten globule state of papain by urea, Biochem. Biophys. Res. Commun. 290 (2002) 1441-1446.

[13] D. Eliezer, P.A. Jennings, H.J. Dyson, P.E. Wright, Populating the equilibrium molten globule under conditions suitable for structural characterization by NMR, FEBS Lett. 417 (1997) 9296.

[14] N. Taddei, C. Capanni, F. Chiti, M. Stefani, C.M. Dobson, G. Ramponi, Folding and aggregation are selectively influenced by the conformational preferences of the alpha-helices of muscle acylphosphatase, J. Biol. Chem. 276 (2001) 37149-37154.

[15] M.F. Perutz, B.J. Pope, D. Owen, E.E. Wanker, E. Scherzinger, Aggregation of proteins with expanded glutamine and alanine repeats of the glutamine-rich and asparagine-rich domains of Su35 and of the amyloid $\beta$-peptide of amyloid plaques, Proc. Natl. Acad. Sci. USA 99 (2002) 5596-5600.

[16] F. Chiti, N. Taddei, F. Baroni, C. Capanni, M. Stephani, G. Ramponi, C.M. Dobson, Kinetic partitioning of protein folding and aggregation, Nat. Struct. Biol. 9 (2002) 137-143.

[17] M.F. Jobling, X. Huang, L.R. Stewart, K.J. Barnham, C. Curtain, I. Volitakis, M. Perugini, A.R. White, R.A. Cherny, C.L. Masters, C.J. Barrow, S.J. Collins, A.I. Bush, R. Cappai, Copper and zinc binding modulates the aggregation and neurotoxic properties of the prion peptide prP106-126, Biochemistry 40 (2001) 8073-8084.

[18] C.M. Dobson, The structural basis of protein folding and its links with human disease, Phil. Trans. R. Soc. Lond. B 356 (2001) 133145 .

[19] A. Neagu, M. Neagu, A. Dér, Fluctuations and the Hofmeister effect, Biophys. J. 81 (2001) 1285-1294.

[20] G. Zardeneta, P.M. Horowitz, Detergent, liposome, and micelleassisted protein refolding, Anal. Biochem. 223 (1994) 1-6.

[21] T. Arakawa, S.N. Timasheff, Stabilization of protein structure by sugars, Biochemistry 21 (1982) 6536-6544.

[22] S.H. McLaughlin, S.E. Jackson, Prot. Sci. 11 (2002) 1926-1936.

[23] X. Chang, D. Keller, S.I. O'Donoghue, J.J. Led, NMR studies of the aggregation of glucagon-like peptide-1: formation of a symmetric helical dimer, FEBS Lett. 515 (2002) 156-170.
[24] R.E. Cappel, H.F. Gilbert, Thiol/disulfide exchange between 2hydroxy-3-methylglutaryl-CoA reductase and glutathione. A thermodynamically facile dithiol oxidation, J. Biol. Chem. 263 (1988) 12204-12212.

[25] R.L. Baldwin, How Hofmeister ion interactions affect protein stability, Biophys. J. 71, 2056-2063.

[26] S.N. Timasheff, Control of protein stability and reactions by weakly interacting cosolvents: the simplicity of the complicated, Adv. Prot. Chem. 51 (1998) 355-432.

[27] K. Collins, M.W. Washabaugh, The Hofmeister effect and the behavior of water at interafaces, Q. Rev. Biophys. 18 (1985) 323422.

[28] F. Hofmeister, Zur Lehre von der Wirkung der Salze. Zweite Mittheilung, Arch. Exp. Pathol. Pharmakol. 24 (1888) 247-260.

[29] G. Xie, S.N. Timasheff, Mechanisms of the stabilization of ribonuclease A by sorbitol: preferential hydration is great for the denatured than for the native protein, Prot. Sci. 6 (1997) 211221.

[30] G. Xie, S.N. Timasheff, Temperature dependence of the preferential interactions of ribonuclease $\mathrm{A}$ in aqueous cosolvent systems: thermodynamic analysis, Prot. Sci. 6 (1997) 222-232.

[31] G.P. Pal, J.S. Elce, Z. Jia, Dissociation and aggregation of calpain in the presence of calcium, J. Biol. Chem. 276 (2001) 4723347238.

[32] P.C. Hiemenz, in: Polymer Chemistry, Marcel Dekker, New York, 1984 , p. 663, 701-709.

[33] L. Li, K.S. Matthews, Differences in water release with DNA binding by Ultrabithorax and Deformed homeodomains, Biochemistry 36 (1997) 7003-7011.

[34] M.I. Moraitis, H. Xu, K.S. Matthews, Ion concentration and temperature dependence of DNA binding: comparison of PurR and LacI repressor proteins, Biochemistry 40 (2001) 8109-8117.

[35] P.A. Whitson, J.S. Olson, K.S. Matthews, Thermodynamic analysis of the lactose repressor-operator DNA interaction, Biochemistry 25 (1986) 3852-3858.

[36] J. Chen, K.S. Matthews, Subunit dissociation affects DNA binding in a dimeric lac repressor produced by C-terminal deletion, Biochemistry 33 (1994) 8728-8735.

[37] C.M. Falcon, K.S. Matthews, Glycine insertions in the hinge region of lactose repressor protein alters DNA binding, J. Biol. Chem. 274 (1999) 30849-30857.

[38] K. Gekko, T. Morikawa, Preferential hydration of bovine serum albumin in polyhydric alcohol-water mixtures, J. Biochem 90 (1981) 39-50.

[39] K. Gekko, S.N. Timasheff, Mechanism of protein stabilization by glycerol: preferential hydration in glycerol-water mixtures, Biochemistry 20 (1981) 4667-4676.

[40] Millipore Technical Support, personal communication.

[41] R.A.H. White, M. Wilcox, Protein products of the bithorax complex in Drosophila, Cell 39, 163-171.

[42] O.P. Zoueva, J.E. Bailey, R. Nicholls, E.G. Brown, Aggregation of influenza virus ribonucleocapsids at low $\mathrm{pH}$, Virus Res. 85 (2002) 141-149.

\section{Further reading}

[1] T.M. DeSilva, J.A. Ursitti, D.W. Speicher, in: J.E. Coligan, B.M. Dunn, D.W. Speicher, P.T. Wingfield (Eds.), Current Protocols in Protein Science, Wiley, New York, 1988, p. 10.5.11. 